\title{
Reform of Practical Teaching Mode of Public Security Administrative Law in the Platform of Cooperation of School and Bureau of Public Security
}

\author{
Qiao Wang \\ National Police University of China, Shenyang, 110854, China
}

\begin{abstract}
Keywords: Public Security Administrative Law; Cooperation of school and bureau of public security; Problems; requirements
\end{abstract}

\begin{abstract}
Cooperation of school and bureau of public security rises in recent years as a training mode for application-oriented talents, mainly for personnel training in police colleges. Police talent education includes theoretical knowledge education and professional practice education. Compared to other professions, this profession puts more emphasis on cultivating of practical ability. Therefore, faced with the requirements of practice-oriented training in police education, taking the method of joint education mode of cooperation of police educational institutions and public security departments is a proper choice to further promote the talent training and great development of education.
\end{abstract}

\section{Public Security Administrative Law}

Public security administration refers to national public security departments' behaviors of management, organization, control and maintenance of public affairs, which aims to safeguard the security and stability of the entire society. On this basis, public security administrative law is the legal norms and scientific guaranteed which public security should comply with when they implement these behaviors. Public security administrative law, based on the public security administrative statute and regulations, combined with the current development results and latest academic research of administration theory, by analyzing and studying the public security administrative practices, further specifies and embodies the requirements and guidelines of Chinese public security administration. Public security administrative law is a branch of administrative law in our country, which is a more specific and detailed administrative regulation. It, combined with appropriate practical experience, boasts the significant features of being practical, feasible and theoretical, which is an important part of China's legal education.

\section{Problems of Practical Teaching of Administrative Law}

Despite the growing importance has been attached to teaching of public security administrative law, there are still 5 problems existing in the old teaching practice:

\section{Teaching ignores the important role of practice}

Law is a highly specialized expertise. In daily education and learning, in order to have a better quality of professional legal knowledge, teachers focus on teaching basic types of law, basic meaning and significance of law, and students put emphasis on memorizing the connotation of law. In this theoretical teaching, students majoring in law only know what the law is but don't know how to use the law, being eloquent about the law but having only empty talk when they need to apply it. This is a major problem in current teaching practice------ignoring the practice of public security administrative law.

\section{A complete system of teaching of administrative law has not yet formed}

This problem is mainly manifested in the current teacher-oriented education mode, not allowing students to play full of their autonomy. Take the case of professor of administrative law as an 
example, the correct answer is always the standard answer, student's answer resembles the standard answer more, the student is tend to get the higher score. As a result, the significance of practice and initiative thinking are ignored.

\section{Student's overall quality is poor}

Public security administrative law is a combination of practical and theoretical learning. Lack of practice for a long term badly affects student's professional legal quality, resulting in the inadequacy of application ability, independent thinking of law and poor overall quality of students.

\section{Lack of good mentors}

Teacher with both the practical experience and professional knowledge ensures to cultivate high-quality talent. But the reality that lack of the mentors having both of the abilities leads to the problems in the teaching of administrative law.

\section{Complete practical teaching base has not yet been established}

Teaching of administrative law specially needs practice, but there is no established and comprehensive bases for practice, teaching bases and places, and there is few off-campus learning space for legal learning. Common legal practice in school is moot court, but because of financial problems, conditions of moot court are far from the real court. Practices such as participating in a real courtroom or getting an internship in public security department are even rare.

\section{Cooperation of School and Bureau of Public Security}

\section{Concept of Cooperation of School and Bureau of Public Security}

Cooperation of school and bureau of public security refers to the mutual cooperation and contact between police college and public security departments, to make full play of the advantages of both sides. It is an advanced teaching mode and working mechanism which can promote multi-level and multi-faceted talent training and the development of mutual benefits. It also manifests the openness and scale of modern police college. Cooperation of school and bureau of public security is an important direction of development in education of public utilities, which aims at training outstanding talent, professional security police and administrative personnel. Through the professional establishment of Public Security Administrative Law and development of mode of police affairs, we can promote the contact and cooperation of police colleges and public security departments. The purpose of cooperation of school and bureau of public security is to cultivate talents. By the innovative personnel training mode of cooperation of school and bureau of public security, we can cultivate more talents who have firm stand, strong overall quality, broad vocational skills and high professional capacity to public security departments.

\section{Significances of Cooperation of School and Bureau of Public Security}

In cooperation of school and bureau of public security, school contacts public security departments initiatively, broadening its own educational scope and focusing on the practical training, to meet the needs of public security posts. For the entire development of talents, it has great significances:

1). School integrates the resources and strengthens the contact of academic education and practical education. In the process of cooperation of school and bureau of public security, we should focus on both the training of theoretical basics and the training of practical ability, which can ensure the formation of a good teaching mechanism in school.

2). There are relatively stable practice bases. Schools pay attention to students' practical ability, public security departments focus on the outside talents, these conditions provide students relative stable bases for learning and practice. The formation of a stable base, likes fertile soil for students to grow, has a great significance for the training of students' practical ability. 
3). Public security police departments have a strong reserve of personnel resources, constantly improving their own quality. When teaching interns of police college, public security officers train their own teaching and practical ability. Public security police departments are allowed to choose excellent interns to participate in their work in the future. Cooperation of school and bureau of public security is conducive to the development of human resources reserve, and to enhance the overall quality level of the public security departments.

4). Cooperation of school and bureau of public security is a win-win and complementary cooperation. Schools focus on teaching theories while public security departments put emphasis on practice. Receiving education of these two areas, students can make up the single and barren educational deficiencies, and schools can cultivate students of more comprehensive quality.

\section{Important role played by Cooperation of School and Bureau of Public Security}

To further cultivate talents to fit into society, some experiential learning methods of cooperation of school and bureau of public security appear, which play an important role in 4 aspects in teaching, as follows:

1). Cooperation of school and bureau of public security can help school to teach the students to meet the standards of public security office, and cultivate students' professional qualities and practical abilities.

2). The application of cooperation of school and bureau of public security can enhance the link between teaching department and practice department in campus and make students fully understand the needs of public security on personnel requirements.

3). Through this practice, teachers can lead students to master the theories of public security, learn the ability to use tools and software with profession. Once receiving the practical learning, students' operational capacity can be enhanced greatly, which is inadequate in theoretical education in campus.

4). Educated students meet the needs of the job market, so teaching can become more targeted and practical. By participating in practical learning, students can be more aware of the professional skills which they need to grasp. They are able to give full play of their initiative. At the same time, schools can add advancing knowledge in teaching. Therefore, cooperation of school and bureau of public security has significant influence on strengthening the training of talent's profession.

\section{Training Objective of Cooperation of School and Bureau of Public Security}

1). Training application-oriented talents with practical ability. Application-oriented talent should have solid theoretical knowledge, and good practical ability and professional proficiency. Training talents' application and practice is one of the most important goals of cooperation of school and bureau of public security.

2). Promoting the development of police colleges. To spread the prestige of police colleges by training of professional talents and establishment of scientific teaching system. It is another important goal of cooperation of school and bureau of public security to set up clear educational philosophy, highlight the school characteristics and to achieve the development of schools.

3). Promoting the training of human resources of reserve and the sustainable development of public security departments. During the process of training talents in colleges and universities, further promoting students in police colleges to transform to public security officer also makes an effort to actually reserve personnel for the entire public security.

4). Creating an atmosphere of cooperation of school and bureau of public security with emphasis on application-oriented talents. Cooperation of school and bureau of public security pays attention to the application of talents. Training batch after batch of professional personnel with good practical ability can help the society to form an atmosphere where educational practice is important, which in turn could also be counterproductive in the retraining of talents. 


\section{Current Practical Cooperation of School and Bureau of Public Security Direction of Practical Cooperation of School and Bureau of Public Security}

Currently, there are some problems such as poor comprehensive quality of students and non-emphasis on practice in teaching of administrative law, so for the learning of administrative law, there are some new methods of cooperation of school and bureau of public security. For teaching by cooperation of school and bureau of public security, there are 4 requirements as followed:

1). Continue to nurture talents according to the needs of public security posts. There is a great benefit to carry out cooperation of school and bureau of public security that students are able to practice through job and learn on grass-root work. The requirements of public security posts for students' quality are the requirements of the whole industry and society for talents of administrative law. Only one knows the demands of market can he carry out the most comprehensive education for students.

2). Accelerate the interaction between talents and public security posts, and strengthen students' practical training. We should establish the cooperation of campus and public security departments, construct good win-win cooperation mode and accelerate the training of professional personnel. We can further enhance students' professional skills through teachers' and students' participation in public security work and by inviting public security officers to have training seminars and investigation courses.

3). Enrich internship base and enhance the quality of students. We should strengthen the ties of school and public security department and hold professional training courses. By hiring professional instructors to have specialized teaching with examples of work, we can make students know clearly about their work ethic, their duties and responsibilities. If school frequently holds joint teaching activities and practical work with public security departments, students' practical experience can be enriched and their professional skills can be developed.

4). Launch extensive activities of school ad public security departments and establish win-win system of cooperation of school and bureau of public security. Schools should have more activities such as badminton contest and basketball contest with these departments to enhance their emotional connection. At the same time, schools should dispatch students to study and practice at the jurisdiction to improve their quality, establish win-win system of cooperation of school and bureau of public security and developing mutual intimate feelings.

\section{Methods of Practical Cooperation of School and Bureau of Public Security}

\section{Strengthen connection with public security departments and cultivate shortage talents together}

School should dispatch professional instructors to involve in the work of public security departments and to learn the workflow of public security departments, further improving instructors' analysis of realistic examples. We should change the status quo that there is only theory in teaching programs and further cultivate talents understanding the era connotation; by leading students to participate in internships in public security departments and work on grass-root jobs, working for citizens, to understand the quality that the public security posts need and to enhance students' self-learning ability. To widely spread pragmatic ideas by holding lectures of instructors from public security departments.

Focus on education of other professions

The mode of cooperation of school and bureau of public security can be beneficial to promote the training and development of talents in police colleges, reducing the problems caused by emphasis on theory and ignoring of practice. So, on the base of cooperation among colleges and universities, we should increase the number of professions to take part in practice. We should not only pay attention to students of security management, but also enhance the quality training of police college students of other professions such as computer security and criminal science and technology. By focusing on the education and cultivation of students in several different professions, we can further expand the scope of cooperation of school and bureau of public security. 
In the process of cooperation of school and bureau of public security, we should focus on the importance of practice

The most important point to strengthen self-learning ability and innovation of police college students is to let them participate in practical work. They should seriously deal with things for people to understand the functions and tasks of public security departments. They should work out their own working moral and practical consciousness from practice, which is an important criterion of personnel training in cooperation of school and bureau of public security.

To strengthen students' professional ethics and skills and other practical skills in cooperation of school and bureau of public security

Public security work requires highly specialized skills, including maintaining the right work attitude and work style, the need for professional operation of instrument and so on. All these things could not be learned from police colleges, but can be learned from model public security officer in work. Therefore, training this kind of operation ability will be able to promote the overall development of students.

To promote the overall improvement and development of cooperation of school and bureau of public security through students' practical education

Cooperation of school and bureau of public security is very important for training students' practical ability, but its development is still not perfect, for example: only a small number of public security departments take part in the cooperation, a few police colleges have this kind of cooperation, the cooperation of school and bureau of public security is not stable and so on. Faced with the shortcomings in current development and other problems that may occur in the future, we should take it seriously, and continuously improve the cooperation in daily work to make full use of the cooperation of school and bureau of public security.

\section{Conclusion}

In a summary, practice is the sole criterion for testing truth, the training of public security personnel couldn't be done without practice. Nowadays, police colleges focus only on theoretical education, and it is a common phenomenon that police colleges ignore practical training. Study on cooperation of school and bureau of public security can help us to understand the meaning of public security administrative law, learn about the problems in teaching of administrative law, and also know the current situation of talents, demand gap of talents and training purpose of talents in the future. We can also know what we should do in cooperation of school and bureau of public security. Use one sentence to summarize: only through the establishment of the win-win mechanism of cooperation of school and bureau of public security, can we further play the combine action of school and public security departments, doing what one can to help for the talents training of public security.

\section{Acknowledgments}

This article is a part of 2014 ordinary higher education teaching reform project of Liaoning Province, the title of which is Practical Reform of Teaching of Administrative Law in Police College in the Background of Reform of Recruiting and Training System and the project No. of which is UPRP20140252. Project leader: Wang Qiao

\section{References}

[1] Fu Guoliang. Theoretical Study and Practice Exploration of Cooperation of School and Bureau of Public Security. Press of People’s Public Security University of China. 2012

[2] Shen Chengzu. Administrative Law of China’s Public Security. Zhejiang University Press. 2011

[3] Wang Lingyan. Problems and Countermeasures of Practical Teaching of Administrative Law. Journal of Huaihai Institute of Techology (Humanities And Social Sciences Edition).2013(03) 
[4] Zhang Xinhai. Strategic Choice of Public Security Education---On Cooperation of School and Bureau of Public Security. Public security research , 2012(09):234-256

[5] Zhang Ming. On Establishment of Curriculum System of Public Security Administration . Journal of Beijing Police College. 2013(11):13-16

[6] Xu Feng. On the Professional Construction of Public Security Management. Henan Science and Technology. 2014(07):56-59

[7] Jin Huai,Wang Yong,Li Zhili. On the Problems and Relevant Countermeasures of Administrative Law in Practical Teaching. Journal of West Anhui University. 2012(05): 24-36 